(3) Lecanochiton, Maskell. Two species. A very distinct genus.

The two following genera were thought peculiar to New Zealand, but are now known from elsewhere:-

(I) Eriochiton, Maskell. The only species referred to this genus from elsewhere than New Zealand is E. cajan, Maskell, which is in reality a Ceroplastodes; but Mr. E. E. Green (in litt.) tells me that he has just received a genuine Eriochilon from Australia.

(2) Solenophora, Maskell. This is now known from North America and Ceylon.

I have no doubt at all that all of the truly native species of New Zealand Coccidæe are strictly endemic. The only apparent exception is that of Eriococcus multispinus, Maskell, which is said to occur in Australia on Acacia; but the Australian form was separated by Maskell as a distinct variety (var. laevigatus), and is doubtless a valid species. T. D. A. Cockereli. Mesilla Park, New Mexico, U.S.A., January 26.

\section{The Fitting of the Cycle to its Rider.}

THERE is much interesting theory in your paper on the bicycle fitted to the rider in crank and gear, by $\mathrm{Mr}$. Crompton (p. 87). But what is the practice? I agree with Mr. Crompton's theories, if a slight modification be made. I think that the crank-length should be proportional not only to a man's thigh-length, but to the weight of a man's leg. The loss of power in a bicycle, as soon as it travels fast, arises from the loss of momentum at each up and down stroke of the leg according to the wcll-known equation :-

$$
\mathrm{M}=m \cdot v \text {. }
$$

Where $\mathrm{M}=$ momentum.

$$
\begin{aligned}
m & =\text { mass. } \\
v & =\text { velocity } .
\end{aligned}
$$

A slender-built man with a light, thin (even although long) leg, can afford a higher value for $v$ because his constant for $m$ is low.

Not so the strongly-built man with a high constant for $m$. He must keep his velocity down, or $M$ rises in value and there is a loss of power at each stroke when travelling fast.

Let me give an illustration. A few days ago I was riding an $8^{\prime \prime}$ crank and 84 gear machine rather fast on a down grade. I travelled swiftly but easily. In front of me was a low-geared cyclist, his feet flying round at a high speed, the bicycle frame quivering with the velocity of his strokes, the cyclist breathing hard with his exertions. As I overhauled him I heard a pedestrian remark against his scorching. Certainly he was scorching in the sense of strongly exerting himself, but his exertions were mainly expended in the lost momentum of each stroke. The only remedy for this is a high gear.

Admitting the advantage of a high gear, the necessity for long cranks follows, otherwise the cyclist has not the power to face hills, winds, or bad roads. Two inches increased crank-length gives an enormously increased power of propulsion. I find that with $8^{\prime \prime}$ cranks and 84 gear I can climb hills easier than with an ordinary roadster, say with $61^{\prime \prime}$ cranks and 64 gear.

The increased comfort and safety on a bicycle fitted as $\mathrm{Mr}$. Crompton recommends are very remarkable and pleasing. The ampler free motion does away with most leg-weariness and saddle-soreness. The long, powerful cranks give one a com mand over the bicycle that is equally satisfactory up-hill or down-hill. One gets over the ground with a long, easy swing Compared with the ordinary bicycle, it is like the outside edge and the inside edge in skating; or like rowing with sliding or fixed seats.

For track riding it seems possible that short cranks and high gears may give the best return for the muscular power exertion expended, since $v$ is kept down by the high gear, and $m$ probably represents the limb of an active young athlete weighing perhaps io stone. And, since there is little resistance to be overcome, the long crank may represent an unnecessary high lift of the leg.

Conversely, the greatest advantage is to be derived from long cranks and high gears in a hilly and difficult country, or where the winds are strong, as here at the Cape, and when the rider has a heavy, powerful leg.

Long cranks and high gears necessitate an alteration to the frame of the bicycle that is troublesome to makers. And hence,

$$
\text { NO. I } 581 \text {, VOL. } 61]
$$

I suppose, the curious taboning of the subject in the too-often interested bicycle literature of the day.

D. E. Hutchins. Kolàra, Kenilworth, nr. Cape Town, January 7.

\section{Telephones and Lightning Discharges.}

IN NATURE of February 8, Sir G. G. Stokes suggests an arrangement for hearing a lightning flash in a telephone. To hear the corresponding earth current, it is only necessary to put a telephone in connection with the gas and water pipes of a house. These pipes seem to suffice to entrap the corresponding earth currents, which practically enable the listener to hear the lightning. Flashes invisible in the daylight are quite noisy in the telephone.

Southwood, Torquay.

A. R. HuNT.

\section{THE GEOGRAPHY OF EUROPE.}

FUROPE is undoubtedly the most refractory of the great divisions of the earth to get within the limits of a geographical treatise. The mass and variety of data of high scientific accuracy are so overwhelming that it is impossible for any one man to make himself acquainted with even a small fraction of the whole, and the compilation of a book on Europe, even on the generous scale which two volumes permits, cannot in the nature of the case be much more than a compilation of earlier compilations. In unskilled hands it could not fail to become a heterogeneous collection of facts ; but Mr. Chisholm has brought to bear experience and expert knowledge in the choice and co-ordination of his material, and the result is a credit to British geography. It shows a great amount of reading amongst original, and sometimes not very accessible, works in many languages, which few compilers would have considered it necessary to undertake in preparing a volume in a popular series. Numerous references are given throughout to the sources of information, and we hope that the second volume will be furnished with a bibliography of the best works dealing with Europe as a whole, and with its larger regions.

The plan of the "Compendium" has always been to take the country rather than the continent as the unit, and by doing so its scientific character has suffered, because the only possible element of unification has been ignored. $\mathrm{Mr}$. Chisholm has endeavoured, with considerable success, to improve the plan of his volume by an excellent introductory chapter dealing with Europe in general, although this, to our mind, is too short; while the individual countries appear to be described in disproportionate detail. In a series obviously intended to convey inform. ation rather than to inculcate geographical principles this disproportion is, however, inevitable, and it is doubtless recognised more fully by the author than by the critic.

The guiding principle which has been kept in view throughout all the descriptions of countries is that the character of a country at the present time is due to the influence of the physical structure of the land upon the historical development of the nation. Hence a good many geological and historical facts are mentioned; but they are mentioned, not as facts for their own sakes, but as working causes accounting for the present adjustment of peoples to lands. The application of this principle has led Mr. Chisholm to commence his detailed descrip. tion with Italy, which he treats with great fulness on account of its historical importance. He gives to the central. Mediterranean peninsula nearly twice as much space as to Russia or France, and a third more than to the German empire. Interesting as Italy is, and vast as was its influence on all Europe, we confess that we should

1 Stanford's "Compendium of Geography and Travel (New Issue) Europe. Vol. I. The Countries of the Mainland (excluding the Northwest)." By Geo. G. Chisholm, M.A., B.Sc. Maps and Illustrations. Pp $\mathrm{xx}+736$. (London: Edward Stanford, r89.) 
hesitate to give it so marked a pre-eminence from the geographical point of view.

Considerable stress is laid upon the importance of town-sites and the growth of towns. This is as it should be ; and we would gladly have seen the peculiarities of every important town-site made clearer by means of small plans, such as are employed in Reclus' great work, and in a few modern atlases. There are excellent general and local maps, in some cases specially prepared, in others adapted from old maps, and in these instances bristling with unnecessary and sometimes mis-spelt place-names, and over one hundred pictorial illustrations, most of which are well chosen. The photograph we reproduce shows the site of Amalfi, concerning which Mr. Chisholm says, in explaining its commercial supremacy over Naples in the Middle Ages: "one may con. jecture that in those troubled times merchants felt more secure on a site so well defended by nature on the side of the land as Amalf." The disastrous landslip which occurred since the book was published gives a hint of the price exacted by nature from the posterity of the merchants who acquired this defended position.

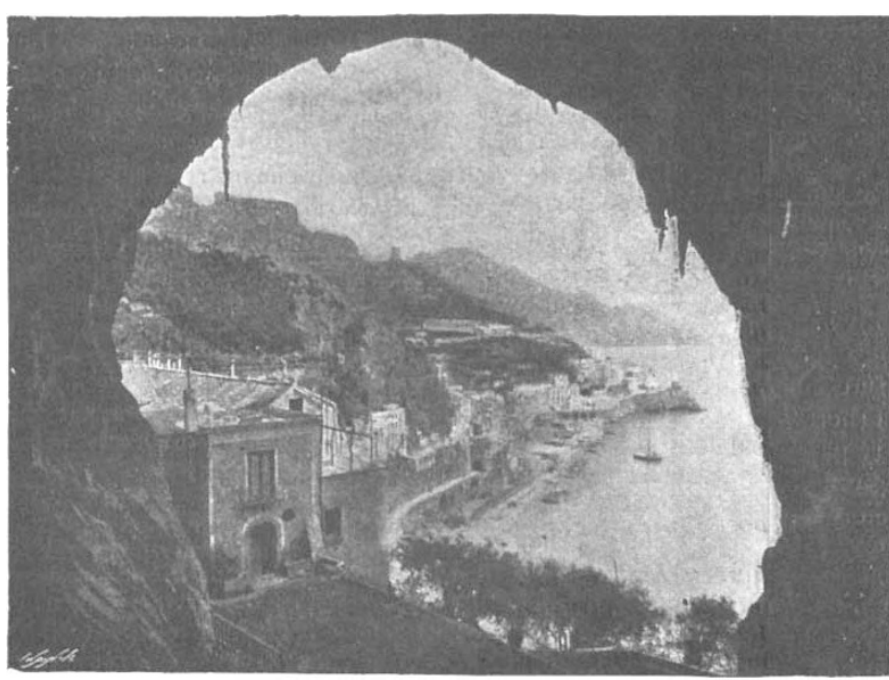

Fig, r.-Amalfi.

Not the least interesting part of the book is furnished by the footnotes and parentheses, which abound in curious or illustrative statements in the tersest form. These are often explanations of the forms of placenames, or the pronunciation of the more uncouth Slavonic consonants, or the briefest comparative statistics. Mr. Chisholm has studied the question of geographical orthography, and introduces some forms of Russian transliteration not usually employed, such as the terminal letter $\tilde{n}$. The difficult matter of the rendering of the Russian $e$ is not yet fully grappled with, its phonetic value $v e$ is not, for instance, given in the case of Ekaterinburg, nor in Kiev. The spelling Kossack is surely wrong; if the usual form Cossack (which occurs in one place) is departed from, the only reasonable forms to adopt would appear to be Kossak or Kosak. These, however, are matters which do not affect the quality or the value of the book.

Amongst the larger maps it is interesting to notice one of the geology of Europe, in which the colour-scheme of the International Geological Map is employed. It has a striking and interesting appearance; but its legibility would be improved by the adoption of reference initials, to enable similar colours to be distinguished. The Permian and Devonian, in particular, are very much alike in small patches.

HUGH ROBERT MILL.

\section{THE UNIVERSITY OF LONDON ELECTION.}

THE University of London has preserved its dignity by returning Sir Michael Foster as its Parliamentary representative. From the commencement of the contest he led the way, and when the poll was declared on Monday the numbers were : Sir Michael Foster, I27 I; Dr. Collins, 863 ; and Mr. Busk, 586.

That such a large majority should have been obtained, in spite of the fact that Sir Michael Foster entered the field nearly a fortnight after his opponents, is a result which was scarcely anticipated by the most sanguine of his supporters, and is therefore all the more satisfactory. It shows that the majority of the electors are capable of taking a broad view of their responsibilities, and that a University constituency is not influenced by the political practices found successful elsewhere. The graduates may rest assured that Sir Michael Foster will guard their privileges, and promote the progress of Science and Learning in the House of Commons. The following remarks, made by the new member for the University after the declaration of the poll on Monday, as reported in the Times, will convince the whole body of graduates that a representative in every respect worthy of the electorate has been sent to Parliament.

Sir Michael Foster said that the graduates had for the first time in the history of the University returned to Parliament one of themselves. He wished to be allowed to state how deeply he felt the honourable and proud position in which they had placed him. He took it that in the main they sent him to Parliament, not that he should add one more unit to this party or to that, but that he should place at the disposal of the House the somewhat special experience which he had gained in science and learning. But the Government of this country was by party, and there were only two sides to the House, on one of which he must sit. Even if he were the superior person he had been called by some newspapers, he could not expect to sit in an isolated chair, and he must respond to the lash of the Whips of one side or the other. He had carefully considered on which side of the House he should sit, and he had come to the conclusion that it was only consistent with the opinions which he had expressed concerning the present war, and with the feelings which he had as to the supreme importance of strengthening the bonds of our great colonies with this little island, that he should first of all, at all events, take his seat among the supporters of the present Government. But he took it that he might so order his ways that he did not sacrifice to party demands, or jeopardise by party action, the opportunities that he might have of forwarding in the House all interests of science, learning and education. He was subject to tradition. As one who was born in the same town as Oliver Cromwell, who was married from the house in which he $\mathrm{dwelt}$, as one whose forefathers-obeying what they thought their consciences - sheltered their friend John Bunyan when he preached outlaw sermons in the woods of Hertfordshire, he felt that tradition wrapped him so about that the war cry of civil and religious liberty always made him prick his ears. Without saying what exact meaning in the new order which had given place to the old might be attached to those words, it at least meant this to him - that the affairs of the nation should not be conducted either to the detriment or to the advantage of any particular set of religious opinions. He believed that that was not his tradition only, but the tradition of that University. The University began as University College, and that college was founded, not simply for local reasons, but to afford the highest academical training to those to whom access was more or less denied to the older Universities. And he had a tradition in the University itself. To the University in its old form he owed all that he had. It had made him what he was. Did they think it was likely, therefore, that he should take any steps which he believed

NO. I $58 \mathrm{I}, \mathrm{VOL} .6 \mathrm{I}]$ 